\title{
Impact of Environmental Factors on Differences in Quality of Medication Use: An Insight for the Medicare Star Rating System
}

\author{
Vibha Desai, PhD; David Nau, PhD; Mark Conklin, PharmD, MS; and Pamela C. Heaton, PhD
}

\begin{abstract}
BACKGROUND: The Medicare star ratings system incentivizes health plan sponsors based on their performance across a measurement system that contains quality measures related to medication use. As health plan sponsors seek to further engage their network providers, specifically network pharmacies, to improve performance on these measures, it is important to consider the effect of environmental factors on the performance of network pharmacies.
\end{abstract}

OBJECTIVE: To determine the effect of environmental factors on pharmacy quality as measured by (a) medication adherence for noninsulin diabetes medications, (b) medication adherence for renin angiotensin receptor antagonists (RASA), (c) medication adherence for cholesterol medications (statins), and (d) use of high-risk medications (HRM) in the elderly.

METHODS: The EQuIPP database, which contains performance information for pharmacies for a nationwide sample of Medicare beneficiaries, was used for this analysis. Environmental factors included regions or characteristics of a community or county. County-level data was obtained from the Area Health Resource Files, a resource product available from the Health Resources \& Service Administration. A logistic regression model was developed with performance as the dependent variable and regions and environmental factors as independent variables. Performance and county characteristics, such as proportion of patients in an age group, race, income, or number of outpatient visits, were classified as high and low based on a median cutoff of nationwide performance scores.

RESULTS: A total of 28,950 pharmacies were included in this analysis. For most measures, the proportion of low-performing pharmacies was significantly higher in the East South Central, Mid-Atlantic, Mountain, Pacific, and West South Central regions. Pharmacies in counties with high median income, high proportion of elderly population (aged $>84$ years), high proportion of elderly patients who were white or Hispanic, high proportion of elderly males, and high proportion of elderly urban patients were less likely to have low performance, whereas those with high proportion of elderly African Americans and high density of independent pharmacies were more likely to have low performance $(P<0.05-0.0001)$.

CONCLUSIONS: This study found that environmental characteristics of a region, including pharmacy and sociodemographic characteristics, explained regional variation in quality measures related to medication use for patient populations served by pharmacies. This evaluation serves to further inform the discussion regarding case-mix adjustment of quality measures and provides information that may be important to further refine intervention strategies for pharmacies and pharmacists who serve certain regional populations. Additionally, pharmacies in greatest need of support for quality improvement may be those who serve populations that are predominantly low income and elderly African American.

J Manag Care Spec Pharm. 2016;22(7):779-86

Copyright $\odot 2016$, Academy of Managed Care Pharmacy. All rights reserved.

\section{What is already known about this subject}

The star rating system for Medicare Part D includes several quality measures related to medication use.

Medicare payment models and public reports on Medicare plan quality may incentivize improved quality of medication use and patient safety.

\section{What this study adds}

This study evaluated the impact of environmental factors, using Medicare data, on regional variation in the quality of medication use among pharmacies.

The influence of environmental factors-sociodemographic, cultural, or otherwise-on health behaviors may be a significant predictor of performance independent of the care-providing capabilities of individuals or organizations.

The findings of this analysis suggest that pharmacies in greatest need of support for quality improvement may be those who serve populations that are predominantly low income and elderly African American

T he star rating system for Medicare Part D includes several quality measures related to medication use, which were developed by the Pharmacy Quality Alliance (PQA). For example, measures of medication adherence and use of high-risk medications in the elderly are important indicators of the quality of medication use, which especially affects the health outcomes of patients with chronic health conditions. Poor quality of medication use is associated with the progression of disease and an increase in morbidity and mortality. ${ }^{1-6}$ Moreover, while it is difficult to measure the economic impact of poor quality of medication use, it is costly. The estimated cost of nonadherence to medication is approximately $\$ 300$ billion per year, and the estimated cost of preventable adverse drug events is $\$ 3.5$ billion. ${ }^{7.8}$

Medicare payment models and public reports on Medicare plan quality may provide incentives for the improvement of medication use and patient safety. Currently, the Medicare Part $\mathrm{C}$ and D star rating system does not account for factors such as severity of illness or sociodemographic characteristics of beneficiaries, ${ }^{9}$ which may disincentivize certain plans. Recently, the Centers for Medicare \& Medicaid Services (CMS), along with 
the RAND Corporation, found that plans with a high percentage of dual eligible enrollees, enrollees who receive low-income subsidies, or enrollees who are disabled were mostly disadvantaged in their ability to achieve high star ratings. ${ }^{10}$ Because the star ratings have been affected by patient demographics, CMS is now evaluating how to best risk adjust the ratings. Given that this risk adjustment is necessary, it is important to understand the impact of other variables and whether further risk adjustment is needed. There is limited information on how star ratings are affected by provider, patient, and environmental factors.

Differences among patients could be viewed at either the individual patient level or at the community or environmental level. Social influences specific to a patient's environment may affect that patient's health behaviors. ${ }^{11}$ Several models and theories describe the influence of environmental factors, which include interpersonal relationships, organizations, and neighborhood communities, on patient health behaviors. ${ }^{12-15}$ Environmental factors also include characteristics of a store or geographic region, which represent the economic and cultural characteristics of the people and organizations residing within the region or who frequent a particular store.

Recent studies have shown the importance of controlling for patient and environmental factors. At the patient level, Dharmarajan et al. (2014) found that age, race, sex, and lowincome subsidy significantly predicted pharmacy quality and that the scores adjusted for these factors were more robust compared with the unadjusted scores. ${ }^{16}$ When comparing the adjusted scores with the unadjusted scores, the unadjusted score methodology failed to identify 39\%-43\% of those pharmacies within the top or bottom $20 \%$. At the environmental level, the quality of medication use varied by geographic region. ${ }^{17-20}$ Variations across regions existed despite adjusting for patient-level factors such as age, race, sex, income, and education level. Store-level environmental factors, such as neighborhood population characteristics, also affected primary medication adherence. ${ }^{17}$ Interestingly, research that applied geospacial mapping to health-related questions supports the idea that health may be affected by environmental factors. ${ }^{21,22}$

While region- and some store-level characteristics have been studied, there is a lack of knowledge regarding how other environmental factors affect quality measures. The purpose of this study was to examine differences in environmental factors that influence a pharmacy's quality performance. Specifically, the objective for this study was to determine the effect of environmental factors on pharmacy quality as measured by (a) medication adherence for noninsulin diabetes medications, (b) medication adherence for renin angiotensin receptor (RASA) antagonists, (c) medication adherence for cholesterol medications (statins), and (d) use of high-risk medications (HRM) in the elderly.

\section{Methods}

\section{Study Design and Period}

This study was a retrospective claims database study, which used the EQuIPP database for pharmacy performance information. The EQuIPP database contained performance information for pharmacies covering 11.7 million Medicare beneficiaries at the time of this study. The measurement period for analysis was January 1, 2014-June 30, 2014.

\section{Store Selection}

The cohort of pharmacies was divided into the following 9 divisions based on their geographic locations and the U.S. Census: New England, Mid-Atlantic, East North Central, West North Central, South Atlantic, East South Central, West South Central, Mountain, and Pacific (see Appendix A for a list of states, available in online article). Pharmacies excluded from the analysis were those classified by the National Council for Prescription Drug Programs as government pharmacies, alternate dispensing pharmacies, long-term care pharmacies, mail order pharmacies, home infusion therapy providers, nonpharmacy dispensing sites, Indian Health Service pharmacies, Veterans Administration pharmacies, institutional pharmacies, managed care organization pharmacies, durable medical equipment outlets, clinic pharmacies, specialty pharmacies, nuclear pharmacies, and military pharmacies. Also excluded from the analysis were pharmacies with $\leq 10$ patients meeting the inclusion criteria for a specific measure.

\section{Primary Outcome Measure}

Four quality performance measures, as developed and specified by PQA, were used to obtain the primary outcome measure: (1) proportion of days covered for noninsulin diabetes medications (PDC Diabetes), (2) proportion of days covered for RASA antagonists (PDC RASA), (3) proportion of days covered for statins (PDC Statins), and (4) use of high-risk medications in the elderly (HRM). PQA technical specifications are based on the proportion of days covered (PDC) method to measure adherence from prescription claims data. ${ }^{23}$ These store-level performance measures are available in the EQUiPP database. Pharmacies with performance scores in the bottom $50 \%$ of the performance scores across the pharmacies in the United States were categorized as low-performing pharmacies, while those in the top 50\% were categorized as high-performing pharmacies.

\section{Covariates}

The primary independent variable was geographic region. Covariates were calculated with county-level or store-level data. County-level data on age, race, sex, ethnicity, education, income, health professional shortage area (HPSA), and urban population were obtained from the Area Health Resource Files, a resource product available from the Health Resources \& 
Impact of Environmental Factors on Differences in Quality of Medication Use: An Insight for the Medicare Star Rating System

TABLE 1 Proportion of Low-Performing Pharmacies by Quality Measure and Region

\begin{tabular}{|c|c|c|c|c|c|c|c|c|c|c|c|c|}
\hline \multirow[b]{2}{*}{ Region } & \multicolumn{3}{|c|}{ PDC Diabetes } & \multicolumn{3}{|c|}{ PDC RASA } & \multicolumn{3}{|c|}{ PDC Statins } & \multicolumn{3}{|c|}{ HRM Use in Elderly } \\
\hline & 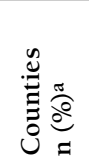 & 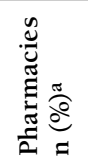 & 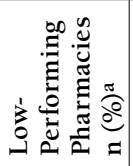 & 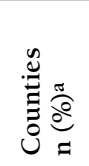 & 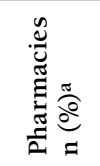 & 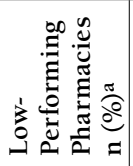 & 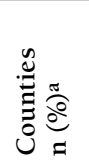 & 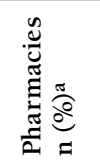 & 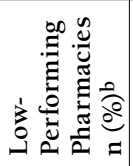 & 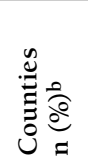 & 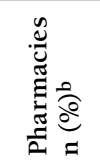 & 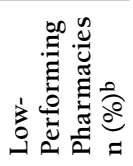 \\
\hline East North Central & $\begin{array}{r}143 \\
(12.0)\end{array}$ & $\begin{array}{l}580 \\
(6.4)\end{array}$ & $\begin{array}{r}264 \\
(45.5)\end{array}$ & $\begin{array}{r}312 \\
(16.3)\end{array}$ & $\begin{array}{l}2,332 \\
(11.3)\end{array}$ & $\begin{array}{r}949 \\
(40.7)\end{array}$ & $\begin{array}{r}296 \\
(16.3)\end{array}$ & $\begin{array}{l}2,083 \\
(10.9)\end{array}$ & $\begin{array}{r}896 \\
(43.0)\end{array}$ & $\begin{array}{r}386 \\
(17.3)\end{array}$ & $\begin{array}{l}4,326 \\
(15.0)\end{array}$ & $\begin{array}{l}1,857 \\
(42.9)\end{array}$ \\
\hline East South Central & $\begin{array}{r}247 \\
(20.8)\end{array}$ & $\begin{array}{l}1,493 \\
(16.5)\end{array}$ & $\begin{array}{c}779 \\
(52.2)^{\mathrm{c}}\end{array}$ & $\begin{array}{r}338 \\
(17.6)\end{array}$ & $\begin{array}{l}3,028 \\
(11.3)\end{array}$ & $\begin{array}{l}1,700 \\
(56.1)^{d}\end{array}$ & $\begin{array}{r}331 \\
(18.3)\end{array}$ & $\begin{array}{l}2,794 \\
(14.7)\end{array}$ & $\begin{array}{l}1,498 \\
(53.6)^{d}\end{array}$ & $\begin{array}{r}352 \\
(15.8)\end{array}$ & $\begin{array}{l}3,454 \\
(12.0)\end{array}$ & $\begin{array}{l}1,827 \\
(52.9) \mathrm{d}\end{array}$ \\
\hline Mid-Atlantic & $\begin{array}{r}72 \\
(6.1)\end{array}$ & $\begin{array}{l}1,870 \\
(20.7)\end{array}$ & $\begin{array}{r}923 \\
(49.4)\end{array}$ & $\begin{array}{r}99 \\
(5.2)\end{array}$ & $\begin{array}{l}2,994 \\
(14.5)\end{array}$ & $\begin{array}{l}1,530 \\
(51.1)^{\mathrm{d}}\end{array}$ & $\begin{array}{r}92 \\
(5.1)\end{array}$ & $\begin{array}{l}2,930 \\
(15.4)\end{array}$ & $\begin{array}{l}1,502 \\
(51.3)^{d}\end{array}$ & $\begin{array}{r}113 \\
(5.1)\end{array}$ & $\begin{array}{l}3,703 \\
(12.8)\end{array}$ & $\begin{array}{l}1,824 \\
(49.3) \mathrm{d}\end{array}$ \\
\hline Mountain & $\begin{array}{r}48 \\
(4.0)\end{array}$ & $\begin{array}{r}214 \\
(2.4)\end{array}$ & $\begin{array}{c}119 \\
(55.6)^{\mathrm{c}}\end{array}$ & $\begin{array}{r}94 \\
(4.9)\end{array}$ & $\begin{array}{r}1,060 \\
(5.1)\end{array}$ & $\begin{array}{r}451 \\
(42.6)\end{array}$ & $\begin{array}{r}85 \\
(4.7)\end{array}$ & $\begin{array}{c}876 \\
(4.6)^{c}\end{array}$ & $\begin{array}{c}340 \\
(38.8)^{c}\end{array}$ & $\begin{array}{r}110 \\
(4.9)\end{array}$ & $\begin{array}{r}1,866 \\
(6.5)\end{array}$ & $\begin{array}{c}996 \\
(53.4)^{\mathrm{d}}\end{array}$ \\
\hline New England & $\begin{array}{r}5 \\
(0.4)\end{array}$ & $\begin{array}{r}33 \\
(0.4)\end{array}$ & $\begin{array}{c}21 \\
(63.6)^{c}\end{array}$ & $\begin{array}{r}16 \\
(0.8)\end{array}$ & $\begin{array}{r}109 \\
(0.5)\end{array}$ & $\begin{array}{r}53 \\
(48.6)\end{array}$ & $\begin{array}{r}14 \\
(0.8)\end{array}$ & $\begin{array}{r}99 \\
(0.5)\end{array}$ & $\begin{array}{r}45 \\
(45.5)\end{array}$ & $\begin{array}{r}23 \\
(1.0)\end{array}$ & $\begin{array}{r}227 \\
(0.8)\end{array}$ & $\begin{array}{r}112 \\
(49.3)\end{array}$ \\
\hline Pacific & $\begin{array}{r}20 \\
(1.7) \\
\end{array}$ & $\begin{array}{r}153 \\
(1.7) \\
\end{array}$ & $\begin{array}{c}98 \\
(64.1)^{\mathrm{d}}\end{array}$ & $\begin{array}{r}32 \\
(1.7)\end{array}$ & $\begin{array}{r}594 \\
(0.5) \\
\end{array}$ & $\begin{array}{c}321 \\
(54.0)^{\mathrm{d}}\end{array}$ & $\begin{array}{r}33 \\
(1.8)\end{array}$ & $\begin{array}{r}507 \\
(2.7) \\
\end{array}$ & $\begin{array}{c}256 \\
(50.5)^{\mathrm{d}}\end{array}$ & $\begin{array}{r}43 \\
(1.9)\end{array}$ & $\begin{array}{r}1,250 \\
(4.3)\end{array}$ & $\begin{array}{r}558 \\
(44.6)\end{array}$ \\
\hline South Atlantic & $\begin{array}{r}356 \\
(30.0)\end{array}$ & $\begin{array}{l}2,859 \\
(31.6)\end{array}$ & $\begin{array}{l}1,335 \\
(46.7)\end{array}$ & $\begin{array}{r}492 \\
(25.7)\end{array}$ & $\begin{array}{l}6,328 \\
(30.6)\end{array}$ & $\begin{array}{l}3,005 \\
(47.5)\end{array}$ & $\begin{array}{r}475 \\
(26.2)\end{array}$ & $\begin{array}{l}5,930 \\
(31.1)\end{array}$ & $\begin{array}{l}2,877 \\
(48.5)\end{array}$ & $\begin{array}{r}534 \\
(24.0)\end{array}$ & $\begin{array}{l}8,016 \\
(27.8)\end{array}$ & $\begin{array}{c}4,169 \\
(52.0)^{\mathrm{d}}\end{array}$ \\
\hline West North Central & $\begin{array}{r}110 \\
(9.3)\end{array}$ & $\begin{array}{r}558 \\
(6.2)\end{array}$ & $\begin{array}{r}248 \\
(44.4)\end{array}$ & $\begin{array}{r}224 \\
(11.7)\end{array}$ & $\begin{array}{r}1,385 \\
(6.7)\end{array}$ & $\begin{array}{r}547 \\
(39.5)\end{array}$ & $\begin{array}{r}210 \\
(11.6)\end{array}$ & $\begin{array}{r}1,316 \\
(6.9)\end{array}$ & $\begin{array}{c}450 \\
(34.2) \mathrm{d}\end{array}$ & $\begin{array}{r}301 \\
(13.5)\end{array}$ & $\begin{array}{r}2,065 \\
(7.2)\end{array}$ & $\begin{array}{r}1,212 \\
(8.4)\end{array}$ \\
\hline West South Central & $\begin{array}{r}186 \\
(15.7) \\
\end{array}$ & $\begin{array}{l}1,286 \\
(14.2)\end{array}$ & $\begin{array}{c}737 \\
(57.3)^{\mathrm{d}}\end{array}$ & $\begin{array}{r}311 \\
(16.2) \\
\end{array}$ & $\begin{array}{r}2,853 \\
(13.8)\end{array}$ & $\begin{array}{c}1,627 \\
(57.0) \mathrm{d}\end{array}$ & $\begin{array}{r}277 \\
(15.3) \\
\end{array}$ & $\begin{array}{l}2,540 \\
(13.3)\end{array}$ & $\begin{array}{c}1,413 \\
(55.6)^{\mathrm{d}}\end{array}$ & $\begin{array}{r}367 \\
(16.5) \\
\end{array}$ & $\begin{array}{l}3,962 \\
(13.7)\end{array}$ & $\begin{array}{l}1,890 \\
(47.7)^{\mathrm{d}}\end{array}$ \\
\hline Total & 1,187 & 9,046 & 4,524 & 1,918 & 20,683 & 10,183 & 1,813 & 19,075 & 9,277 & 2,229 & 28,869 & 14,445 \\
\hline
\end{tabular}

apercentage of column total.

bercentage of total pharmacies.

$c P<0.05$.

$d P<0.0001$

$H R M=$ high-risk medication; $P D C=$ proportion of days covered; $R A S A=$ renin angiotensin receptor antagonist.

Service Administration. ${ }^{24}$ The county-level data were linked to store-level data using ZIP codes that had county names and ZIP codes in which the pharmacies were located. The following characteristics were calculated for each county:

- Proportion of the elderly population aged $>64$ or $>84$ years

- Proportion of the elderly population that was white versus African American, Asian, or Hispanic

- Proportion of the population with a college degree

- Median income

- Proportion of urban population

- Health professional shortage (HPSA)

- Proportion of chain pharmacies versus independent pharmacies

- Proportion of pharmacies that had a high volume of patients

These characteristics, except HPSA, were characterized as high or low based on a median cutoff point. Store characteristics were obtained from the EQuIPP database. Store volume was the number of Medicare Advantage patients in a store for a specific measure. Pharmacy type was classified as either independent or chain.

\section{Analysis}

The proportion of low-performing pharmacies was calculated for each of the regions, and chi-square tests were performed to determine significant differences in the distribution of lowperforming pharmacies across the regions. The ranges that defined the performance and the variables as high and low are listed in Appendices B and C (available in online article). East North Central, the region with a consistent percentage of lowperforming stores, was used as the reference region. Logistic regression was performed with low-performing pharmacies as the dependent variable and the region, county-level, and store characteristics as the independent variables. Pearson correlation coefficient of 0.7 was used to detect multicollinearity between the variables. When multicollinearity was detected, 1 of the variables was removed from the regression model. All analyses were conducted using SAS, version 9.4 (SAS Institute, Cary, NC). This project was designated as exempt from the University of Cincinnati Institutional Review Board.

\section{Results}

At least 1 of the 4 performance measures was calculated for 28,969 pharmacies. The number of pharmacies varied by region, and for each measure, the number of pharmacies 


\begin{tabular}{|c|c|c|c|c|c|c|c|c|c|c|c|c|c|c|}
\hline Region & & 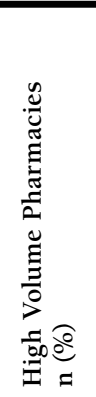 & 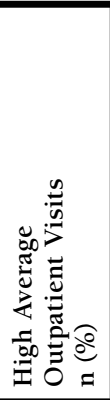 & 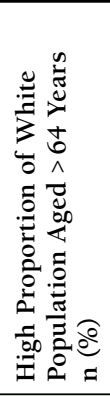 & 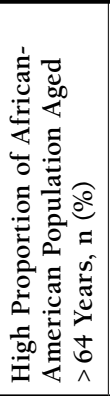 & 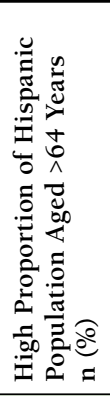 & 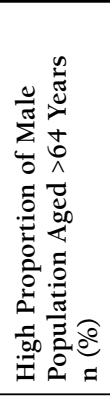 & 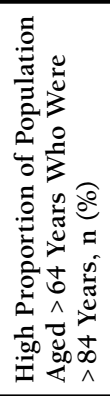 & 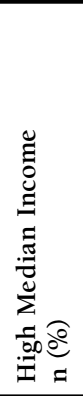 & 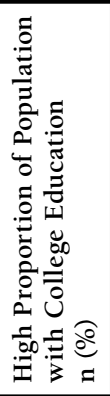 & 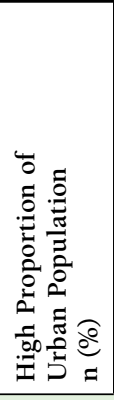 & 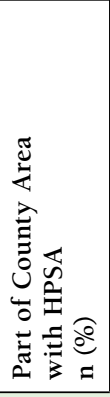 & 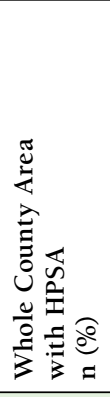 & 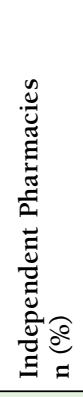 \\
\hline \multicolumn{15}{|l|}{ PDC Diabetes } \\
\hline $\begin{array}{l}\text { East North } \\
\text { Central }\end{array}$ & 580 & $\begin{array}{r}164 \\
(28.3) \\
\end{array}$ & $\begin{array}{r}430 \\
(74.1) \\
\end{array}$ & $\begin{array}{r}333 \\
(57.4) \\
\end{array}$ & $\begin{array}{r}244 \\
(42.1) \\
\end{array}$ & $\begin{array}{r}259 \\
(44.7) \\
\end{array}$ & $\begin{array}{r}298 \\
(51.4) \\
\end{array}$ & $\begin{array}{r}495 \\
(85.3) \\
\end{array}$ & $\begin{array}{r}418 \\
(72.1) \\
\end{array}$ & $\begin{array}{r}302 \\
(52.0) \\
\end{array}$ & $\begin{array}{r}270 \\
(46.6) \\
\end{array}$ & $\begin{array}{r}310 \\
(53.5) \\
\end{array}$ & $\begin{array}{r}221 \\
(38.1) \\
\end{array}$ & $\begin{array}{r}30 \\
(5.2) \\
\end{array}$ \\
\hline $\begin{array}{l}\text { East South } \\
\text { Central }\end{array}$ & 1,493 & $\begin{array}{r}709 \\
(47.5) \\
\end{array}$ & $\begin{array}{r}629 \\
(42.1)\end{array}$ & $\begin{array}{r}786 \\
(52.7)\end{array}$ & $\begin{array}{r}679 \\
(45.5) \\
\end{array}$ & $\begin{array}{r}12 \\
(0.8)\end{array}$ & $\begin{array}{r}551 \\
(36.9) \\
\end{array}$ & $\begin{array}{r}326 \\
(21.8) \\
\end{array}$ & $\begin{array}{r}519 \\
(34.8) \\
\end{array}$ & $\begin{array}{r}553 \\
(37.0)\end{array}$ & $\begin{array}{r}244 \\
(16.3)\end{array}$ & $\begin{array}{r}261 \\
(17.5)\end{array}$ & $\begin{array}{r}798 \\
(53.5) \\
\end{array}$ & $\begin{array}{r}375 \\
(25.1) \\
\end{array}$ \\
\hline Mid-Atlantic & 1,870 & $\begin{array}{l}1,091 \\
(58.3)\end{array}$ & $\begin{array}{l}1,519 \\
(81.2)\end{array}$ & $\begin{array}{r}953 \\
(51.0)\end{array}$ & $\begin{array}{l}1,151 \\
(61.6)\end{array}$ & $\begin{array}{l}1,074 \\
(57.4)\end{array}$ & $\begin{array}{r}919 \\
(49.1)\end{array}$ & $\begin{array}{l}1,861 \\
(99.5)\end{array}$ & $\begin{array}{l}1,056 \\
(56.5)\end{array}$ & $\begin{array}{l}1,024 \\
(54.8)\end{array}$ & $\begin{array}{l}1,201 \\
(64.2)\end{array}$ & $\begin{array}{r}923 \\
(49.4) \\
\end{array}$ & $\begin{array}{r}888 \\
(47.5) \\
\end{array}$ & $\begin{array}{r}825 \\
(44.1) \\
\end{array}$ \\
\hline Mountain & 214 & $\begin{array}{r}57 \\
(26.6)\end{array}$ & $\begin{array}{r}62 \\
(29.0)\end{array}$ & $\begin{array}{r}124 \\
(57.9)\end{array}$ & $\begin{array}{r}2 \\
(0.9)\end{array}$ & $\begin{array}{r}206 \\
(96.3)\end{array}$ & $\begin{array}{r}87 \\
(40.7)\end{array}$ & $\begin{array}{r}19 \\
(8.9)\end{array}$ & $\begin{array}{r}149 \\
(69.6)\end{array}$ & $\begin{array}{r}63 \\
(29.4)\end{array}$ & $\begin{array}{r}123 \\
(57.5)\end{array}$ & $\begin{array}{r}151 \\
(70.6)\end{array}$ & $\begin{array}{r}61 \\
(28.5)\end{array}$ & $\begin{array}{r}11 \\
(5.1)\end{array}$ \\
\hline New England & 33 & $\begin{array}{r}10 \\
(30.3)\end{array}$ & $\begin{array}{r}7 \\
(21.2)\end{array}$ & $\begin{array}{r}33 \\
(100.0)\end{array}$ & 0 & $\begin{array}{r}31 \\
(93.9)\end{array}$ & $\begin{array}{r}32 \\
(97.0)\end{array}$ & $\begin{array}{r}32 \\
(97.0)\end{array}$ & $\begin{array}{r}32 \\
(97.0)\end{array}$ & $\begin{array}{r}32 \\
(97.0)\end{array}$ & $\begin{array}{r}31 \\
(93.9)\end{array}$ & $\begin{array}{r}6 \\
(18.2)\end{array}$ & $\begin{array}{r}27 \\
(81.9)\end{array}$ & $\begin{array}{r}2 \\
(6.1)\end{array}$ \\
\hline Pacific & 153 & $\begin{array}{r}41 \\
(26.8)\end{array}$ & $\begin{array}{r}49 \\
(32.0) \\
\end{array}$ & $\begin{array}{r}8 \\
(5.2) \\
\end{array}$ & $\begin{array}{r}1 \\
(0.7)\end{array}$ & $\begin{array}{r}149 \\
(97.4)\end{array}$ & $\begin{array}{r}96 \\
(62.8) \\
\end{array}$ & $\begin{array}{r}55 \\
(36.0) \\
\end{array}$ & $\begin{array}{r}127 \\
(83.0)\end{array}$ & $\begin{array}{r}60 \\
(39.2) \\
\end{array}$ & $\begin{array}{r}102 \\
(66.7) \\
\end{array}$ & $\begin{array}{r}108 \\
(70.6)\end{array}$ & $\begin{array}{r}45 \\
(29.4)\end{array}$ & $\begin{array}{r}27 \\
(17.7)\end{array}$ \\
\hline South Atlantic & 2,859 & $\begin{array}{l}1,465 \\
(51.2)\end{array}$ & $\begin{array}{r}779 \\
(27.3)\end{array}$ & $\begin{array}{l}1,399 \\
(48.9)\end{array}$ & $\begin{array}{l}1,614 \\
(56.5)\end{array}$ & $\begin{array}{l}1,670 \\
(58.4)\end{array}$ & $\begin{array}{l}1,674 \\
(58.6)\end{array}$ & $\begin{array}{l}1,205 \\
(42.2)\end{array}$ & $\begin{array}{l}1,207 \\
(42.2)\end{array}$ & $\begin{array}{l}1,643 \\
(57.5)\end{array}$ & $\begin{array}{l}1,557 \\
(54.5)\end{array}$ & $\begin{array}{r}414 \\
(14.5)\end{array}$ & $\begin{array}{l}2,138 \\
(74.8)\end{array}$ & $\begin{array}{r}417 \\
(14.6)\end{array}$ \\
\hline $\begin{array}{l}\text { West North } \\
\text { Central }\end{array}$ & 558 & $\begin{array}{r}261 \\
(46.8) \\
\end{array}$ & $\begin{array}{r}318 \\
(57.0) \\
\end{array}$ & $\begin{array}{r}425 \\
(76.2) \\
\end{array}$ & $\begin{array}{r}133 \\
(23.8) \\
\end{array}$ & $\begin{array}{r}162 \\
(29.0) \\
\end{array}$ & $\begin{array}{r}299 \\
(53.6) \\
\end{array}$ & $\begin{array}{r}408 \\
(73.1) \\
\end{array}$ & $\begin{array}{r}300 \\
(53.8) \\
\end{array}$ & $\begin{array}{r}352 \\
(63.0) \\
\end{array}$ & $\begin{array}{r}253 \\
(34.0) \\
\end{array}$ & $\begin{array}{r}48 \\
(8.6)\end{array}$ & $\begin{array}{r}474 \\
(85.0)\end{array}$ & $\begin{array}{r}105 \\
(18.8) \\
\end{array}$ \\
\hline $\begin{array}{l}\text { West South } \\
\text { Central }\end{array}$ & 1,286 & $\begin{array}{r}677 \\
(52.6) \\
\end{array}$ & $\begin{array}{r}733 \\
(57.0) \\
\end{array}$ & $\begin{array}{r}519 \\
(40.4) \\
\end{array}$ & $\begin{array}{r}697 \\
(54.2) \\
\end{array}$ & $\begin{array}{r}965 \\
(75.0) \\
\end{array}$ & $\begin{array}{r}572 \\
(44.5) \\
\end{array}$ & $\begin{array}{l}125 \\
(9.7) \\
\end{array}$ & $\begin{array}{r}728 \\
(56.6) \\
\end{array}$ & $\begin{array}{r}495 \\
(38.5) \\
\end{array}$ & $\begin{array}{r}740 \\
(57.5) \\
\end{array}$ & $\begin{array}{r}785 \\
(61.0) \\
\end{array}$ & $\begin{array}{r}415 \\
(32.3) \\
\end{array}$ & $\begin{array}{r}226 \\
(17.6) \\
\end{array}$ \\
\hline
\end{tabular}

varied. The number of pharmacies (range $=2,859-8,016$ pharmacies per measure) was highest in the South Atlantic region, while the number of pharmacies (range $=33-127$ ) in the New England region was the lowest, followed by the Pacific region (range $=153-1,250)$.

Table 1 indicates the proportion of low-performing pharmacies across the 9 regions. For most measures, the proportion of low-performing pharmacies was significantly higher in the East South Central, Mid-Atlantic, Mountain, Pacific, and West South Central regions.

Table 2 shows the distribution of pharmacies stratified by county-level and store level factors across the regions for PDC Diabetes (see Appendix D for other quality measures, available in online article). The county- and store-level factors varied greatly across the regions. For example, the proportion of pharmacies in counties with a high median income ranged from $34.8 \%$ in the East South Central region to $97.0 \%$ in the New England region. The proportion of pharmacies in counties with a high proportion of elderly Hispanics ranged from $0.8 \%$ in the East South Central region to 96.3\% in the Mountain region.
In Table 3, the results of logistic regression predicting the likelihood of low performance of the pharmacies are presented. For most of the quality measures, pharmacies were less likely to have low performance if they were located in counties with high median income, with a high proportion of elderly males, high proportion of elderly Hispanics, or high proportion of elderly who are aged $>84$ years. Independent pharmacies (PDC RASA: odds ratio $[\mathrm{OR}]=1.68,95 \%$ confidence interval $[C I]=1.56-1.80 ; \quad P D C$ Statin: $O R=1.47,95 \% C I=1.37-1.58)$ and pharmacies in counties with a high proportion of elderly African Americans (PDC RASA: OR $=1.61,95 \% \mathrm{CI}=1.46-1.78$; PDC Statin: $\mathrm{OR}=1.53,95 \% \mathrm{CI}=1.38-1.70)$ were more likely to have low performance. Interestingly, pharmacies in counties with a large elderly white population were less likely to have poor performance for measures PDC Diabetes ( $\mathrm{OR}=0.77$, 95\% CI $=0.65-0.91)$, PDC RASA (OR $=0.81,95 \% \mathrm{CI}=0.73$ 0.91), and PDC Statins (OR=0.68, 95\% CI=0.61-0.76), but they were more likely to have poor performance for HRM use in the elderly $(\mathrm{OR}=1.15,95 \% \mathrm{CI}=1.06-1.25)$. Except for the HRM measure, pharmacies in counties with large 


\begin{tabular}{|c|c|c|c|c|c|c|c|c|}
\hline & \multicolumn{2}{|c|}{ PDC Diabetes } & \multicolumn{2}{|c|}{ PDC RASA } & \multicolumn{2}{|c|}{ PDC Statin } & \multicolumn{2}{|c|}{ HRM Use in Elderly } \\
\hline & OR & $95 \% \mathrm{CI}$ & OR & $95 \% \mathrm{CI}$ & OR & $95 \% \mathrm{CI}$ & OR & $95 \% \mathrm{CI}$ \\
\hline \multicolumn{9}{|l|}{ Region } \\
\hline East North Central & reference & & & & & & & \\
\hline East South Central & 0.86 & $0.68-1.07$ & 1.15 & $1.01-1.31$ & 0.99 & $0.87-1.14$ & 1.07 & $0.96-1.18$ \\
\hline Mid-Atlantic & 1.01 & $0.83-1.23$ & 1.23 & $1.10-1.39$ & 1.13 & $1.00-1.27$ & 1.39 & $1.26-1.53$ \\
\hline Mountain & 1.71 & $1.21-2.40$ & 1.34 & $1.13-1.58$ & 0.90 & $0.75-1.07$ & 2.18 & $1.92-2.47$ \\
\hline New England & 4.32 & $2.06-9.06$ & 1.71 & $1.15-2.54$ & 1.30 & $0.86-1.97$ & 1.46 & $1.11-1.93$ \\
\hline Pacific & 2.41 & $1.60-3.62$ & 1.99 & $1.62-2.45$ & 1.26 & $1.01-1.58$ & 1.73 & $1.49-1.99$ \\
\hline South Atlantic & 0.92 & $0.75-1.13$ & 1.00 & $0.89-1.12$ & 0.88 & $0.78-0.99$ & 1.52 & $1.39-1.66$ \\
\hline West North Central & 1.00 & $0.78-1.27$ & 1.01 & $0.88-1.16$ & 0.74 & $0.64-0.86$ & 1.75 & $1.57-1.96$ \\
\hline West South Central & 1.34 & $1.07-1.67$ & 1.47 & $1.30-1.67$ & 1.15 & $1.00-1.31$ & 1.35 & $1.22-1.49$ \\
\hline \multicolumn{9}{|l|}{ Store characteristics } \\
\hline Independent pharmacy & 1.23 & $1.10-1.37$ & 1.68 & $1.56-1.80$ & 1.47 & $1.37-1.58$ & 1.48 & $1.40-1.57$ \\
\hline Chain pharmacy & reference & & & & & & & \\
\hline High-volume pharmacies & 1.01 & $0.92-1.10$ & 1.03 & $0.97-1.09$ & 1.02 & $0.96-1.08$ & 0.90 & $0.86-0.94$ \\
\hline \multicolumn{9}{|l|}{ County-level characteristics } \\
\hline High average number of outpatient visits & 1.01 & $0.91-1.12$ & 1.02 & $0.95-1.08$ & 0.98 & $0.91-1.05$ & 1.17 & $1.11-1.24$ \\
\hline High proportion of white population aged $>64$ years & 0.77 & $0.65-0.91$ & 0.81 & $0.73-0.91$ & 0.68 & $0.61-0.76$ & 1.15 & $1.06-1.25$ \\
\hline $\begin{array}{l}\text { High proportion of African-American population } \\
\text { aged }>64 \text { years }\end{array}$ & 1.38 & $1.18-1.61$ & 1.61 & $1.46-1.78$ & 1.53 & $1.38-1.70$ & 1.08 & $1.00-1.17$ \\
\hline High proportion of Hispanic population aged $>64$ years & 0.78 & $0.69-0.87$ & 0.87 & $0.80-0.94$ & 0.97 & $0.90-1.05$ & 0.73 & $0.69-0.78$ \\
\hline High proportion of male population aged $>64$ years & 0.74 & $0.66-0.84$ & 0.77 & $0.71-0.82$ & 0.80 & $0.74-0.87$ & 0.91 & $0.86-0.97$ \\
\hline $\begin{array}{l}\text { High proportion of population aged }>64 \text { years who } \\
\text { were }>84 \text { years }\end{array}$ & 0.91 & $0.80-1.03$ & 0.91 & $0.84-0.98$ & 0.89 & $0.82-0.97$ & 0.86 & $0.81-0.92$ \\
\hline High median income & 0.74 & $0.66-0.82$ & 0.82 & $0.76-0.88$ & 0.80 & $0.74-9.86$ & 0.88 & $0.83-0.94$ \\
\hline High proportion of population with college education & 0.86 & $0.76-0.97$ & 0.79 & $0.73-0.85$ & 0.81 & $0.75-0.88$ & 1.12 & $1.05-1.19$ \\
\hline Counties with HPSA for part of area & 0.88 & $0.74-1.03$ & 0.83 & $0.75-0.92$ & 0.89 & $0.80-0.99$ & 0.83 & $0.76-0.90$ \\
\hline Counties with HPSA for entire area & 0.81 & $0.69-0.94$ & 0.81 & $0.73-0.89$ & 0.90 & $0.82-1.00$ & 0.87 & $0.80-0.94$ \\
\hline High proportion of urban population & 1.00 & $0.88-1.14$ & 0.91 & $0.84-0.99$ & 0.98 & $0.89-1.06$ & 0.67 & $0.62-0.71$ \\
\hline
\end{tabular}

college- educated populations were less likely to have low performance (PDC Diabetes: $\mathrm{OR}=0.86,95 \% \mathrm{CI}=0.76-0.97$ ).

Differences in performance across regions can be explained by adjusting for environmental factors. For example, the East South Central region, which was significantly more likely to have low-performing pharmacies for all 4 measures, was no longer a low performer (except for PDC RASA) after adjusting for environmental factors. Conversely, while New England did not have a significantly higher proportion of low-performing pharmacies, except for PDC Diabetes, before adjustment, it was significantly more likely to have low-performing pharmacies for all 4 measures, except for PDC Statins, after adjustment of environmental factors.

Similarly, an important finding of this study was the characteristics that explained low performance in the East South Central region, compared with the East North Central region. Before adjustment, the proportion of low-performing pharmacies was significantly higher in the East South Central region for all 4 measures, compared with the East North Central region.
However, after adjustment for environmental factors, the East South Central region was not likely to have low-performing pharmacies, except for the PDC RASA measure. A parsimonious regression was modeled to further explain the factors affecting the difference in the proportion of low-performing pharmacies between the East North Central region and the East South Central region (Table 4). For the measures PDC Diabetes, PDC Statins, and HRM, several covariates predicted performance, such as income, type of pharmacy, age, race, and HSPA. Conversely, for the PDC RASA measure, none of the environmental factors could explain the significant difference.

\section{Discussion}

In this study, the effect of environmental factors on regional variation in the quality of medication use among pharmacies was evaluated, using Medicare data. Of particular interest was the finding that pharmacies in counties with a high proportion of elderly people aged $>84$ years were less likely to have low performance for the PDC RASA, PDC Statins, and 
Impact of Environmental Factors on Differences in Quality of Medication Use: An Insight for the Medicare Star Rating System

TABLE 4 Parsimonious Regression Models Explaining Difference in Performance Between East North Central and East South Central Regions

\begin{tabular}{|c|c|c|c|c|c|c|}
\hline \multirow[b]{2}{*}{ Effect } & \multicolumn{2}{|c|}{ PDC Diabetes } & \multicolumn{2}{|c|}{ PDC Statins } & \multicolumn{2}{|c|}{ HRM Use in Elderly } \\
\hline & OR & $95 \%$ CI & OR & $95 \% \mathrm{CI}$ & OR & $95 \% \mathrm{CI}$ \\
\hline \multicolumn{7}{|l|}{ Regions } \\
\hline East North Central & reference & & & & & \\
\hline East South Central & 0.78 & $0.60-1.01$ & 0.98 & $0.84-1.16$ & 0.98 & $0.87-1.10$ \\
\hline \multicolumn{7}{|l|}{ Store characteristics } \\
\hline Chain pharmacy & reference & & & & & \\
\hline Independent pharmacy & 1.36 & $1.08-1.72$ & 1.42 & $1.23-1.64$ & 1.37 & $1.23-1.53$ \\
\hline \multicolumn{7}{|l|}{ County-level characteristics } \\
\hline High median income & 0.67 & $0.56-0.81$ & 0.74 & $0.65-0.84$ & 0.71 & $0.64-0.79$ \\
\hline High proportion of African-American population aged $>64$ years & 2.48 & $2.04-3.03$ & 2.08 & $1.83-2.37$ & - & - \\
\hline High proportion of population aged $>64$ years who were $>84$ years & 0.63 & $0.49-0.80$ & 0.74 & $0.64-0.86$ & 0.95 & $0.85-1.07$ \\
\hline High proportion of Hispanic population aged $>64$ years & - & - & - & - & 0.57 & $0.49-0.65$ \\
\hline High proportion of urban population & - & - & - & - & 0.96 & $0.86-1.08$ \\
\hline Counties with HPSA for part of area & - & - & - & - & 0.78 & $0.67-0.90$ \\
\hline Counties with HPSA for entire area & - & - & - & - & 0.72 & $0.63-0.82$ \\
\hline R-square & 0.052 & & 0.04 & & 0.04 & \\
\hline
\end{tabular}

$C I=$ confidence interval; HPSA = health professional shortage area; HRM = high-risk medication; OR=odds ratio; PDC = proportion of days covered; $R A S A=$ renin angiotensin receptor antagonist.

HRM measures. Perhaps elderly patients who are dependent on others receive better care than the younger group of the elderly population who take care of themselves. Pharmacies in counties with a high proportion of elderly African Americans were more likely to have low performance for all measures, which was consistent with previous studies regarding race and adherence. ${ }^{25,26}$ Pharmacies in counties with a high proportion of elderly whites were more likely to have low performance for the HRM measure. Additionally, for the HRM measure, pharmacies in counties with patients who had higher income or were in an urban setting were less likely to have poor performance. Pharmacies in counties with a high proportion of elderly Hispanics were less likely to have poor performance for the HRM measure; however, Pugh et al. (2011) found that elderly Hispanics were more likely to receive HRMs between 2004 to $2006 .{ }^{27}$ It is possible that over recent years, along with the implementation of Medicare Part D in 2006, efforts may have been made to reduce the use of HRMs. Recently, a study by Hussein et al. (2014) found that the Hispanic-white disparities in medication adherence decreased after $2006(P<0.02)$, while the black-white disparities in medication adherence still persisted after $2006(P<0.09){ }^{28}$

The results of regional differences in quality of medication use in this study were different from the studies by Couto et al. (2014) and Qato and Trivedi (2013), which evaluated performance measures among Medicare enrollees. ${ }^{17,19}$ These 2 studies found that the New England region had the best rate of medication adherence, followed by the Mid-Atlantic and East North Central regions, compared with the East South Central region (reference), which had the lowest performance. In contrast, this study found that, for all measures, the pharmacies in the East South Central region performed similarly to pharmacies in the East North Central region. This may be explained by the different use of covariates: Couto et al. did not adjust for race, ethnicity, and age $>84$ years, and Qato and Trivedi did not adjust for income and ethnicity.

The findings of this study further add to the body of evidence seeking to define the "nature/nurture" debate regarding health care professional performance on quality measures. This debate centers around how responsible health care professionals, or patient care organizations (pharmacies, in this case), can be for the health behaviors of the population they serve. The influence of environmental factors (e.g, sociodemographic and cultural) on health behaviors are often argued to be significant predictors of performance independent of the care-providing capabilities of individuals or organizations. Pharmacy programs such as automatic refills, medication therapy management, and synchronization of refills can improve adherence, but the success of these programs may also be influenced by environmental factors. What has yet to be determined is whether these findings support the case for risk adjusting the performance of certain organizations being measured, which may accept that lower levels of positive health behaviors will exist among certain populations, or if these findings should be used to improve the ability of health care professionals to understand their populations and refine their interventional tactics to fit the dynamics of those they serve. The findings of this study do not offer a definitive resolution to this debate, but they do support the recent CMS findings regarding the need for risk adjustment and are intended to add to the body of evidence 
that will refine the debate as quality measurement and performance assessment surrounding medication use evolves. Future studies could explore additional associations between quality measure performance and other potential variables known to influence medication-taking behavior (e.g., beliefs influencing the perceived severity of illness and perceived benefits of medication therapy, pharmacists' counseling efforts, and the presence of social-medical support systems for patients).

\section{Limitations}

This study has several limitations. As with all database studies, it is assumed that patients take the prescriptions that they fill. County-level data was used to study the effect of neighborhood population characteristics. Counties are large, and the population characteristics of the counties may not necessarily reflect medication use of patients in the particular ZIP code in which a pharmacy is located. U.S. Census tract-level data could not be used for population characteristics, since a database that merged census tract-level data to the ZIP code-level data of pharmacies in the EQuIPP database was unavailable. Also, health care system variables, such as HPSA and average number of outpatient visits, were only available at the county level from the Area Resource Files. The number of stores varied by region and was particularly small in the New England region, which may limit generalizability within that region.

\section{Conclusions}

This study found that environmental characteristics of a region, including pharmacy and sociodemographic characteristics, explained regional variation in quality of medication use. This evaluation serves to further inform the discussion regarding the case-mix adjustment of quality measures and provides information that may be important to further refine intervention strategies among pharmacies and pharmacists who serve certain regional populations. Additionally, pharmacies in greatest need of support for quality improvement may be those who serve populations that are predominantly low income and elderly African American.

\section{Authors}

VIBHA DESAI, PhD, and PAMELA C. HEATON, PhD, James L. Winkle College of Pharmacy, University of Cincinnati Academic Health Center, Cincinnati, Ohio. DAVID NAU, PhD, and MARK CONKLIN, PharmD, MS, Pharmacy Quality Solutions, Durham, North Carolina.

AUTHOR CORRESPONDENCE: Pamela C. Heaton, PhD, Chair and Associate Professor of Pharmacy Practice and Administrative Sciences, James L. Winkle College of Pharmacy, University of Cincinnati Academic Health Center, 3225 Eden Ave., Cincinnati, OH 45267. Tel.: 513.558.4177. E-mail: heatonp@ucmail.uc.edu.

\section{DISCLOSURES}

Desai's postdoctoral fellowship was funded by Pharmacy Quality Solutions for conducting this study and writing the manuscript. Nau and Conklin are employed by Pharmacy Quality Solutions.

An earlier version of this research was presented as a poster at the Annual Meeting of the Academy of Managed Care Pharmacy; San Diego, CA; April 7-10, 2015.

Study concept and design were contributed by Conklin, Nau, Desai, and Heaton. Desai and Conklin took the lead in data collection, assisted by Nau and Heaton. The manuscript was primarily written by Desai and Heaton, with assistance from Conklin and Nau. All authors contributed to data interpretation and manuscript revision.

\section{REFERENCES}

1. Ho PM, Magid DJ, Shetterly SM, et al. Medication nonadherence is associated with a broad range of adverse outcomes in patients with coronary artery disease. Am Heart J. 2008;155(4):772-79.

2. Rasmussen JN, Chong A, Alter DA. Relationship between adherence to evidence-based pharmacotherapy and long-term mortality after acute myocardial infarction. JAMA. 2007;297(2):177-86.

3. Hope CJ, Wu J, Tu W, Young J, Murray MD. Association of medication adherence, knowledge, and skills with emergency department visits by adults 50 years or older with congestive heart failure. Am J Health Syst Pharm. 2004;61(19):2043-49

4. Pladevall M, Williams LK, Potts LA, Divine G, Xi H, Lafata JE. Clinical outcomes and adherence to medications measured by claims data in patients with diabetes. Diabetes Care. 2004;27(12):2800-05.

5. Lau DT, Nau DP. Oral antihyperglycemic medication nonadherence and subsequent hospitalization among individuals with type 2 diabetes. Diabetes Care. 2004;27(9):2149-53.

6. Fick DM, Mion LC, Beers MH, L Waller J. Health outcomes associated with potentially inappropriate medication use in older adults. Res Nursing Heath. 2008;31(1):42-51.

7. Senst BL, Achusim LE, Genest RP, et al. Practical approach to determining costs and frequency of adverse drug events in a health care network. Am J Heath Syst Pharm. 2001;58(12):1126-32.

8. Bootman JL, Wolcott J, Aspden P, Cronenwett LR. Preventing Medication Errors: Quality Chasm Series. National Academies Press; 2006.

9. National Quality Forum. Risk adjustment for socioeconomic status or other sociodemographic factors. Technical report. August 15, 2014. Available at: http://www.qualityforum.org/Publications/2014/08/Risk_Adjustment_ for_Socioeconomic_Status_or_Other_Sociodemographic_Factors.aspx. Accessed May 13, 2016.

10. Centers for Medicare \& Medicaid Services. Updated research findings on the impact of socioeconomic status on star ratings. September 8, 2015. Available at: https://www.cms.gov/Medicare/Prescription-Drug-Coverage/ PrescriptionDrugCovGenIn/PerformanceData.html. Accessed May 13, 2016.

11. McLeroy KR, Bibeau D, Steckler A, Glanz K. An ecological perspective on health promotion programs. Health Educ Q. 1988;15(4):351-77.

12. Bronfenbrenner U. The Ecology of Human Development: Experiments by Nature and Design. Cambridge, MA: Harvard University Press; 2009.

13. Seidman E. Back to the future, community psychology: unfolding a theory of social intervention. Am J Community Psychol. 1988;16(1):3-24.

14. Jackson T. On the limitations of health promotion. Community Health Stud. 1985;9(1):1-9.

15. Glanz K, Mullis RM. Environmental interventions to promote healthy eating: a review of models, programs, and evidence. Health Educ 2.

1988;15(4):395-415. 
16. Dharmarajan S, Bentley JP, Banahan BF III, West-Strum DS. Measuring pharmacy performance in the area of medication adherence: addressing the issue of risk adjustment. J Manag Care Spec Pharm. 2014;20(10):1057-68. Available at: http://www.jmcp.org/doi/abs/10.18553/jmcp.2014.20.10.1057.

17. Couto JE, Panchal JM, Lal LS, et al. Geographic variation in medication adherence in commercial and Medicare Part D populations. J Manag Care Spec Pharm. 2014;20(8):834-42. Available at: http://www.jmcp.org/doi/ abs/10.18553/jmcp.2014.20.8.834

18. Jackson TH, Bentley JP, McCaffrey DJ 3rd. Store and prescription characteristics associated with primary medication nonadherence. J Manag Care Spec Pharm. 2014;20(8):824-32. Available at: http://www.jmcp.org/doi/ abs/10.18553/jmcp.2014.20.8.824

19. Qato DM, Trivedi AN. Receipt of high risk medications among elderly enrollees in Medicare Advantage plans. J Gen Intern Med. 2013;28:546-53.

20. Tan E, Yang W, Pang B, Dai M, Loh FE, Hogan P. Geographic variation in antidiabetic agent adherence and glycemic control among patients with type 2 diabetes. J Manag Care Spec Pharm. 2015;21(12):1195-202. Available at: http://www.jmcp.org/doi/full/10.18553/jmcp.2015.21.12.1195.

21. Widener MJ, Northridge ME, Chakraborty B, et al. Patterns of chronic conditions in older adults: exploratory spatial findings from the ElderSmile Program. Am J Prev Med. 2014;46(6):643-48.
22. Borrell LN, Northridge ME, Miller DB, et al. Oral health and health care for older adults: a spatial approach for addressing disparities and planning services. Spec Care Dentist. 2006;26(6):252-56.

23. Nau DP. Proportion of days covered (PDC) as a preferred method of measuring medication adherence. Pharmacy Quality Alliance. 2012. Available at: http://ep.yimg.com/ty/cdn/epill/pdcmpr.pdf. Accessed May 13, 2016.

24. Best AE. Secondary data bases and their use in outcomes research: a review of the area resource file and the Healthcare Cost and Utilization Project. J Med Syst. 1999;23(3):175-81

25. Kaplan RC, Bhalodkar NC, Brown EJ Jr, White J, Brown DL. Race, ethnicity, and sociocultural characteristics predict noncompliance with lipidlowering medications. Prev Med. 2004;39(6):1249-55

26. Dominick KL, Golightly YM, Bosworth HB. Racial differences in analgesic/anti-inflammatory medication adherence among patients with osteoarthritis. Ethn Dis. 2005;15(1):11-22

27. Pugh MJV, Hanlon JT, Wang CP, et al. Trends in use of high-risk medications for older veterans: 2004 to 2006. J Am Geriatr Soc. 2011;59(10):1891-98.

28. Hussein M, Waters TM, Solomon DK, Brown LM. The impact of Medicare Part D on racial/ethnic disparities in cardiovascular medication adherence among the elderly. Circ Cardiovasc Qual Outcomes. 2014;7(Suppl 1): Al19 [Abstract]. 


\begin{tabular}{l|l}
\hline \multicolumn{1}{c|}{ APPENDIX A } & Regions \\
\hline New England & $\begin{array}{l}\text { Maine, Massachusetts, New Hampshire, Vermont, } \\
\text { Rhode Island, Connecticut }\end{array}$ \\
\hline Mid-Atlantic & New York, New Jersey, Pennsylvania \\
\hline East North Central & Illinois, Indiana, Michigan, Ohio, Wisconsin \\
\hline West North Central & $\begin{array}{l}\text { Iowa, Kansas, Minnesota, Missouri, Nebraska, } \\
\text { North Dakota, South Dakota }\end{array}$ \\
\hline South Atlantic & $\begin{array}{l}\text { Delaware, Florida, Georgia, Maryland, North } \\
\text { Carolina, South Carolina, Virginia, West Virginia, } \\
\text { District of Columbia }\end{array}$ \\
\hline East South Central & Alabama, Kentucky, Mississippi, Tennessee \\
\hline West South Central & Arkansas, Louisiana, Oklahoma, Texas \\
\hline Mountain & $\begin{array}{l}\text { Arizona, Colorado, Idaho, Montana, Nevada, } \\
\text { New Mexico, Utah, Wyoming }\end{array}$ \\
\hline Pacific & $\begin{array}{l}\text { Alaska, California, Hawaii, Nevada, Oregon, } \\
\text { Washington }\end{array}$ \\
\hline
\end{tabular}

\section{APPENDIX B Performance Definition}

\begin{tabular}{l|c|c|c|c}
\hline Performance & Number & Mean & Minimum & Maximum \\
\hline $\begin{array}{l}\text { PDC Diabetes } \\
\text { Low }\end{array}$ & 4,524 & 75.59 & 30 & 84.3 \\
\hline High & 4,522 & 91.40 & 84.4 & 100 \\
\hline PDC RASA & 10,183 & 77.25 & 27.3 & 85.6 \\
\hline Low & 10,500 & 91.69 & 85.7 & 100 \\
\hline High & 9,277 & 74.67 & 27.3 & 83.2 \\
\hline $\begin{array}{l}\text { PDC Statins } \\
\text { Low }\end{array} 9,798$ & 89.87 & 83.3 & 100 \\
\hline High & 14,445 & 10.45 & 5.8 & 95.2 \\
\hline HRM Use in Elderly & 14,424 & 2.39 & 0 & 5.7 \\
\hline How & Pigh
\end{tabular}

HRM = high-risk medication; $P D C=$ proportion of days covered; $R A S A=$ renin angiotensin receptor antagonist.

\section{APPENDIX C Variable Definition}

\begin{tabular}{|c|c|c|c|c|c|c|c|c|c|c|c|}
\hline 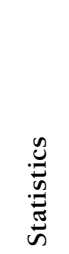 & 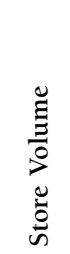 & 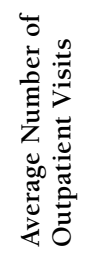 & 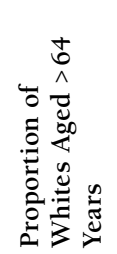 & 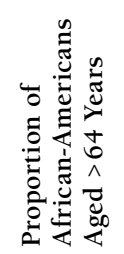 & 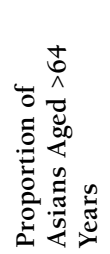 & 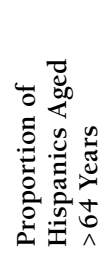 & 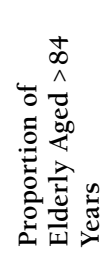 & 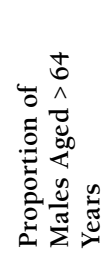 & 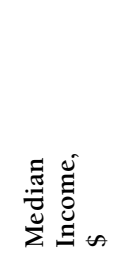 & 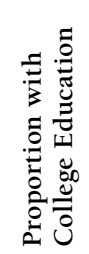 & 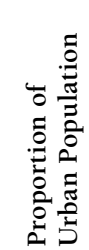 \\
\hline
\end{tabular}

\section{PDC Diabetes}

\begin{tabular}{|c|c|c|c|c|c|c|c|c|c|c|c|c|}
\hline Low & $\mathrm{N}$ & 4,571 & 4,520 & 4,466 & 4,525 & 4,448 & 4,518 & 4,520 & 4,518 & $4,510.00$ & 4,522 & 45 \\
\hline Low & MIN & 10 & 0.00 & 0.14 & 0.00 & 0.00 & 0.00 & 0.04 & 0.30 & $22,148.00$ & 0.04 & 0.00 \\
\hline Low & MAX & 17 & 2.19 & 0.61 & 0.06 & 0.01 & 0.01 & 0.09 & 0.34 & $45,806.00$ & 0.17 & 0.91 \\
\hline High & $\mathrm{N}$ & 4,475 & 4,526 & 4,580 & 4,521 & 4,598 & 4,528 & 4,526 & 4,528 & $4,536.00$ & 4,524 & 45 \\
\hline High & MIN & 18 & 2.20 & 0.61 & 0.06 & 0.01 & 0.01 & 0.09 & 0.34 & $45,813.00$ & 0.17 & 0.91 \\
\hline High & MAX & 321 & 67.25 & 0.79 & 0.51 & 0.47 & 0.68 & 0.19 & 0.39 & $118,934.00$ & 0.42 & 1.00 \\
\hline
\end{tabular}

\section{PDC RASA}

\begin{tabular}{|c|c|c|c|c|c|c|c|c|c|c|c|c|}
\hline Low & $\mathrm{N}$ & 10,472 & 10,340 & 10,344 & 10,342 & 10,321 & 10,356 & 10,341 & 10,340 & $10,351.00$ & 10,316 & 103 \\
\hline Low & MIN & 10 & 0.00 & 0.14 & 0.00 & 0.00 & 0.00 & 0.03 & 0.29 & $22,126.00$ & 0.04 & 0.00 \\
\hline Low & MAX & 24 & 2.14 & 0.61 & 0.05 & 0.01 & 0.01 & 0.09 & 0.34 & $46,396.00$ & 0.17 & 0.88 \\
\hline High & $\mathrm{N}$ & 10,211 & 10,343 & 10,339 & 10,341 & 10,362 & 10,327 & 10,342 & 10,343 & $10,332.00$ & 10,367 & 103 \\
\hline High & MIN & 25 & 2.14 & 0.61 & 0.05 & 0.01 & 0.01 & 0.09 & 0.34 & $46,412.00$ & 0.17 & 0.88 \\
\hline High & MAX & 875 & 67.25 & 0.79 & 0.51 & 0.47 & 0.68 & 0.19 & 0.40 & $118,934.00$ & 0.42 & 1.00 \\
\hline
\end{tabular}

PDC Statins

\begin{tabular}{|c|c|c|c|c|c|c|c|c|c|c|c|c|}
\hline Low & $\mathrm{N}$ & 9,361 & 9,549 & 9,539 & 9,536 & 9,546 & 9,549 & 9,536 & 9,550 & $9,539.00$ & 9,481 & 95 \\
\hline Low & MIN & 10 & 0.00 & 0.14 & 0.00 & 0.00 & 0.00 & 0.03 & 0.29 & $22,126.00$ & 0.04 & 0.00 \\
\hline Low & MAX & 22 & 2.14 & 0.61 & 0.05 & 0.01 & 0.01 & 0.09 & 0.34 & $46,396.00$ & 0.17 & 0.88 \\
\hline High & $\mathrm{N}$ & 9,714 & 9,526 & 9,536 & 9,539 & 9,529 & 9,526 & 9,539 & 9,525 & $9,536.00$ & 9,594 & 96 \\
\hline High & MIN & 23 & 2.14 & 0.61 & 0.05 & 0.01 & 0.01 & 0.09 & 0.34 & $46,412.00$ & 0.17 & 0.88 \\
\hline High & MAX & 900 & 67.25 & 0.79 & 0.51 & 0.47 & 0.68 & 0.19 & 0.39 & $118,934.00$ & 0.42 & 1.00 \\
\hline
\end{tabular}

\section{HRM Use in Elderly}

\begin{tabular}{|c|c|c|c|c|c|c|c|c|c|c|c|c|}
\hline Low & $\mathrm{N}$ & 14,562 & 14,402 & 14,436 & 14,429 & 14,327 & 14,427 & 14,441 & 14,442 & $14,434.00$ & 14,642 & 144 \\
\hline Low & MIN & 10 & 0.00 & 0.14 & 0.00 & 0.00 & 0.00 & 0.03 & 0.29 & $22,126.00$ & 0.03 & 0.00 \\
\hline Low & MAX & 33 & 2.14 & 0.61 & 0.05 & 0.01 & 0.01 & 0.09 & 0.34 & $47,214.00$ & 0.17 & 0.88 \\
\hline High & $\mathrm{N}$ & 14,307 & 14,467 & 14,433 & 14,440 & 14,542 & 14,442 & 14,428 & 14,427 & $14,435.00$ & 14,227 & 145 \\
\hline High & MIN & 34 & 2.14 & 0.61 & 0.05 & 0.01 & 0.01 & 0.09 & 0.34 & $47,227.00$ & 0.17 & 0.88 \\
\hline High & MAX & 1,354 & 67.25 & 0.81 & 0.55 & 0.47 & 0.68 & 0.20 & 0.41 & $121,250.00$ & 0.50 & 1.00 \\
\hline
\end{tabular}

HRM = high-risk medication; $M I N=$ minimum; $M A X=$ maximum; $P D C=$ proportion of days covered; $R A S A=$ renin angiotensin receptor antagonist. 
APPENDIX D Store-Level and County-Level Characteristics by Region for PDC RASA, PDC Statins, and HRM Use in Elderly

\begin{tabular}{|c|c|c|c|c|c|c|c|c|c|c|c|c|c|c|}
\hline $\begin{array}{l}\tilde{\sigma} \\
\ddot{\infty} \\
\ddot{\approx}\end{array}$ & 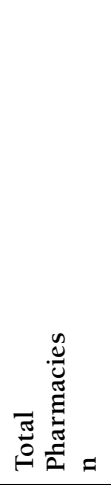 & 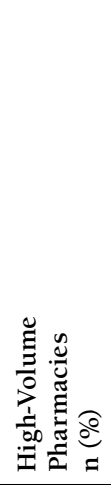 & 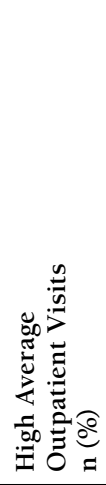 & 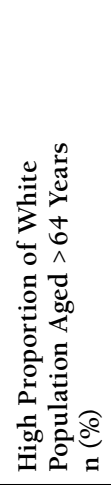 & 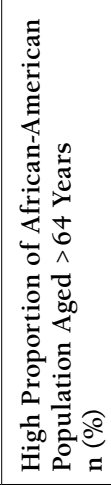 & 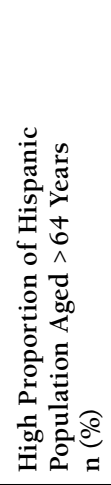 & 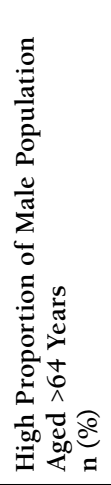 & 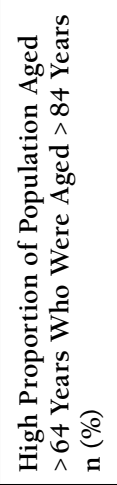 & 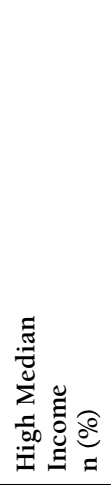 & 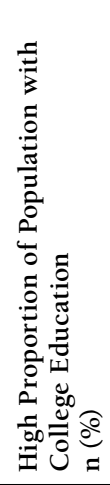 & 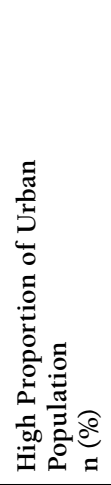 & 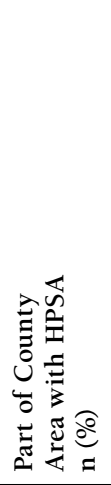 & 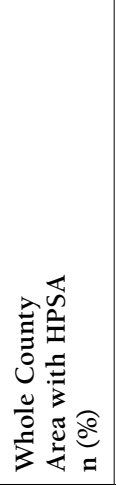 & 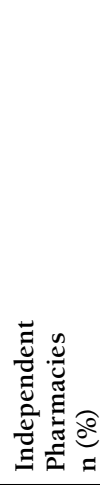 \\
\hline \multicolumn{15}{|l|}{ PDC RASA } \\
\hline $\begin{array}{l}\text { East North } \\
\text { Central }\end{array}$ & 2,332 & $\begin{array}{r}642 \\
(27.5)\end{array}$ & $\begin{array}{r}1656 \\
(71.01)\end{array}$ & $\begin{array}{r}1511 \\
(64.79)\end{array}$ & $\begin{array}{r}845 \\
(36.23)\end{array}$ & $\begin{array}{r}847 \\
(36.32)\end{array}$ & $\begin{array}{r}1,288 \\
(55.23)\end{array}$ & $\begin{array}{r}1,921 \\
(82.38)\end{array}$ & $\begin{array}{r}1,463 \\
(62.74)\end{array}$ & $\begin{array}{r}1,124 \\
(48.20)\end{array}$ & $\begin{array}{r}1,075 \\
(46.10)\end{array}$ & $\begin{array}{r}1,100 \\
(47.17)\end{array}$ & $\begin{array}{r}928 \\
(39.79\end{array}$ & $\begin{array}{r}245 \\
(10.51)\end{array}$ \\
\hline $\begin{array}{l}\text { East South } \\
\text { Central }\end{array}$ & 3,028 & $\begin{array}{r}1,774 \\
(58.6) \\
\end{array}$ & $\begin{array}{l}1,375 \\
(45.4) \\
\end{array}$ & $\begin{array}{r}1,579 \\
(52.2) \\
\end{array}$ & $\begin{array}{l}1,469 \\
(48.5) \\
\end{array}$ & $\begin{array}{r}24 \\
(0.8) \\
\end{array}$ & $\begin{array}{l}1,382 \\
(45.6) \\
\end{array}$ & $\begin{array}{r}852 \\
(28.1) \\
\end{array}$ & $\begin{array}{r}660 \\
(21.8) \\
\end{array}$ & $\begin{array}{l}1,018 \\
(33.6)\end{array}$ & $\begin{array}{r}672 \\
(22.2) \\
\end{array}$ & $\begin{array}{r}638 \\
(21.1) \\
\end{array}$ & $\begin{array}{r}1,654 \\
(54.6\end{array}$ & $\begin{array}{l}1,069 \\
(35.3)\end{array}$ \\
\hline $\begin{array}{l}\text { Mid- } \\
\text { Atlantic }\end{array}$ & 2,994 & $\begin{array}{l}1,891 \\
(63.2) \\
\end{array}$ & $\begin{array}{l}2,364 \\
(79.0)\end{array}$ & $\begin{array}{l}1,643 \\
(54.9) \\
\end{array}$ & $\begin{array}{l}1,734 \\
(57.9)\end{array}$ & $\begin{array}{l}1,668 \\
(55.7) \\
\end{array}$ & $\begin{array}{l}1,508 \\
(50.4) \\
\end{array}$ & $\begin{array}{l}2,961 \\
(98.9) \\
\end{array}$ & $\begin{array}{l}1,732 \\
(57.9)\end{array}$ & $\begin{array}{r}1,750 \\
(58.5) \\
\end{array}$ & $\begin{array}{r}1,879 \\
(62.8) \\
\end{array}$ & $\begin{array}{l}1,354 \\
(45.2)\end{array}$ & $\begin{array}{l}1,501 \\
(50.1 \\
\end{array}$ & $\begin{array}{l}1,282 \\
(42.8) \\
\end{array}$ \\
\hline Mountain & 1,060 & $\begin{array}{r}298 \\
(28.1) \\
\end{array}$ & $\begin{array}{r}347 \\
(32.7) \\
\end{array}$ & $\begin{array}{r}736 \\
(69.4) \\
\end{array}$ & $\begin{array}{r}196 \\
(18.5) \\
\end{array}$ & $\begin{array}{l}1,019 \\
(96.1) \\
\end{array}$ & $\begin{array}{r}546 \\
(51.5) \\
\end{array}$ & $\begin{array}{r}191 \\
(18.0) \\
\end{array}$ & $\begin{array}{r}800 \\
(75.5) \\
\end{array}$ & $\begin{array}{r}604 \\
(57.0) \\
\end{array}$ & $\begin{array}{r}750 \\
(70.8) \\
\end{array}$ & $\begin{array}{r}718 \\
(67.7) \\
\end{array}$ & $\begin{array}{r}326 \\
(30.8 \\
\end{array}$ & $\begin{array}{r}82 \\
(7.8) \\
\end{array}$ \\
\hline $\begin{array}{l}\text { New } \\
\text { England }\end{array}$ & 109 & $\begin{array}{r}33 \\
(30.3) \\
\end{array}$ & $\begin{array}{r}55 \\
(50.5) \\
\end{array}$ & $\begin{array}{r}109 \\
(100.0) \\
\end{array}$ & $\begin{array}{r}79 \\
(72.5) \\
\end{array}$ & $\begin{array}{r}81 \\
(74.3) \\
\end{array}$ & $\begin{array}{r}97 \\
(89.0) \\
\end{array}$ & $\begin{array}{r}100 \\
(91.7) \\
\end{array}$ & $\begin{array}{r}92 \\
(84.4) \\
\end{array}$ & $\begin{array}{r}93 \\
(85.3) \\
\end{array}$ & $\begin{array}{r}79 \\
(72.5) \\
\end{array}$ & $\begin{array}{r}42 \\
(38.5) \\
\end{array}$ & $\begin{array}{r}65 \\
(59.6 \\
\end{array}$ & $\begin{array}{r}18 \\
(16.5) \\
\end{array}$ \\
\hline Pacific & 594 & $\begin{array}{r}140 \\
(23.6) \\
\end{array}$ & $\begin{array}{r}210 \\
(35.4) \\
\end{array}$ & $\begin{array}{r}56 \\
(9.4) \\
\end{array}$ & $\begin{array}{r}12 \\
(2.0) \\
\end{array}$ & $\begin{array}{r}564 \\
(95.0) \\
\end{array}$ & $\begin{array}{r}304 \\
(51.2) \\
\end{array}$ & $\begin{array}{r}263 \\
(44.3) \\
\end{array}$ & $\begin{array}{r}486 \\
(81.8) \\
\end{array}$ & $\begin{array}{r}222 \\
(37.4) \\
\end{array}$ & $\begin{array}{r}466 \\
(78.5) \\
\end{array}$ & $\begin{array}{r}422 \\
(71.0) \\
\end{array}$ & $\begin{array}{r}172 \\
(29.0 \\
\end{array}$ & $\begin{array}{r}83 \\
(14.0) \\
\end{array}$ \\
\hline $\begin{array}{l}\text { South } \\
\text { Atlantic }\end{array}$ & 6,328 & $\begin{array}{l}3,316 \\
(52.4)\end{array}$ & $\begin{array}{l}1,885 \\
(29.8)\end{array}$ & $\begin{array}{l}2,514 \\
(39.7)\end{array}$ & $\begin{array}{l}4,069 \\
(64.3)\end{array}$ & $\begin{array}{l}3,535 \\
(55.9)\end{array}$ & $\begin{array}{l}3,208 \\
(50.7)\end{array}$ & $\begin{array}{l}2,387 \\
(37.7)\end{array}$ & $\begin{array}{l}2,688 \\
(42.5)\end{array}$ & $\begin{array}{l}3,534 \\
(55.9)\end{array}$ & $\begin{array}{l}3,326 \\
(52.6)\end{array}$ & $\begin{array}{l}1,105 \\
(17.5)\end{array}$ & $\begin{array}{r}4,340 \\
(68.6\end{array}$ & $\begin{array}{l}1,340 \\
(21.2)\end{array}$ \\
\hline $\begin{array}{l}\text { West North } \\
\text { Central }\end{array}$ & 1,385 & $\begin{array}{r}691 \\
(49.9) \\
\end{array}$ & $\begin{array}{r}908 \\
(65.6) \\
\end{array}$ & $\begin{array}{l}1,146 \\
(82.7) \\
\end{array}$ & $\begin{array}{r}277 \\
(20.0) \\
\end{array}$ & $\begin{array}{r}479 \\
(34.6) \\
\end{array}$ & $\begin{array}{r}761 \\
(55.0) \\
\end{array}$ & $\begin{array}{l}1,095 \\
(79.1) \\
\end{array}$ & $\begin{array}{r}850 \\
(61.4) \\
\end{array}$ & $\begin{array}{r}853 \\
(61.6) \\
\end{array}$ & $\begin{array}{r}612 \\
(44.2) \\
\end{array}$ & $\begin{array}{r}157 \\
\text { (11.3) }\end{array}$ & $\begin{array}{r}1,099 \\
(79.4 \\
\end{array}$ & $\begin{array}{r}369 \\
(26.6) \\
\end{array}$ \\
\hline $\begin{array}{l}\text { West South } \\
\text { Central }\end{array}$ & 2,853 & $\begin{array}{l}1,426 \\
(50.0) \\
\end{array}$ & $\begin{array}{l}1,543 \\
(54.1) \\
\end{array}$ & $\begin{array}{l}1,045 \\
(36.6) \\
\end{array}$ & $\begin{array}{l}1,660 \\
(58.2) \\
\end{array}$ & $\begin{array}{l}2,110 \\
(74.0) \\
\end{array}$ & $\begin{array}{l}1,249 \\
(43.8) \\
\end{array}$ & $\begin{array}{r}572 \\
(20.1) \\
\end{array}$ & $\begin{array}{l}1,561 \\
(54.7) \\
\end{array}$ & $\begin{array}{l}1,169 \\
(41.0)\end{array}$ & $\begin{array}{l}1,490 \\
(52.2) \\
\end{array}$ & $\begin{array}{l}1,581 \\
(55.4)\end{array}$ & $\begin{array}{r}986 \\
(34.6 \\
\end{array}$ & $\begin{array}{r}671 \\
(23.5) \\
\end{array}$ \\
\hline \multicolumn{15}{|l|}{ PDC Statins } \\
\hline $\begin{array}{l}\text { East North } \\
\text { Central } \\
\end{array}$ & 2,083 & $\begin{array}{r}565 \\
(27.1) \\
\end{array}$ & $\begin{array}{r}1,492 \\
(71.6) \\
\end{array}$ & $\begin{array}{l}1,350 \\
(64.8) \\
\end{array}$ & $\begin{array}{r}761 \\
(36.5) \\
\end{array}$ & $\begin{array}{r}758 \\
(36.4) \\
\end{array}$ & $\begin{array}{l}1,153 \\
(55.4) \\
\end{array}$ & $\begin{array}{l}1,698 \\
(81.5) \\
\end{array}$ & $\begin{array}{r}1,318 \\
(63.3) \\
\end{array}$ & $\begin{array}{r}1,019 \\
(48.9) \\
\end{array}$ & $\begin{array}{r}950 \\
(45.6) \\
\end{array}$ & $\begin{array}{r}978 \\
(47.0) \\
\end{array}$ & $\begin{array}{r}843 \\
(40.5) \\
\end{array}$ & $\begin{array}{r}208 \\
(10.0) \\
\end{array}$ \\
\hline $\begin{array}{l}\text { East South } \\
\text { Central }\end{array}$ & 2,794 & $\begin{array}{l}1,668 \\
(59.7) \\
\end{array}$ & $\begin{array}{l}1,267 \\
(45.4)\end{array}$ & $\begin{array}{l}1,437 \\
(51.4) \\
\end{array}$ & $\begin{array}{l}1,334 \\
(47.8) \\
\end{array}$ & $\begin{array}{r}52 \\
(1.9) \\
\end{array}$ & $\begin{array}{l}1,240 \\
(44.4) \\
\end{array}$ & $\begin{array}{r}722 \\
(25.8) \\
\end{array}$ & $\begin{array}{r}644 \\
(23.1) \\
\end{array}$ & $\begin{array}{r}966 \\
(34.6) \\
\end{array}$ & $\begin{array}{r}636 \\
(22.8) \\
\end{array}$ & $\begin{array}{r}568 \\
(20.3) \\
\end{array}$ & $\begin{array}{l}1,519 \\
(54.4) \\
\end{array}$ & $\begin{array}{r}942 \\
(33.7) \\
\end{array}$ \\
\hline $\begin{array}{l}\text { Mid- } \\
\text { Atlantic } \\
\end{array}$ & 2,930 & $\begin{array}{l}1,892 \\
(64.6) \\
\end{array}$ & $\begin{array}{l}2,302 \\
(78.6) \\
\end{array}$ & $\begin{array}{l}1,620 \\
(55.3) \\
\end{array}$ & $\begin{array}{l}1,684 \\
(57.5) \\
\end{array}$ & $\begin{array}{l}1,615 \\
(55.1) \\
\end{array}$ & $\begin{array}{l}1,486 \\
(50.7) \\
\end{array}$ & $\begin{array}{l}2,901 \\
(99.0) \\
\end{array}$ & $\begin{array}{l}1,674 \\
(57.1) \\
\end{array}$ & $\begin{array}{l}1,698 \\
(58.0) \\
\end{array}$ & $\begin{array}{l}1,823 \\
(62.2) \\
\end{array}$ & $\begin{array}{l}1,332 \\
(45.5) \\
\end{array}$ & $\begin{array}{r}1,459 \\
(49.8) \\
\end{array}$ & $\begin{array}{l}1,266 \\
(43.2) \\
\end{array}$ \\
\hline Mountain & 876 & $\begin{array}{r}239 \\
(27.3) \\
\end{array}$ & $\begin{array}{r}275 \\
(31.4) \\
\end{array}$ & $\begin{array}{r}604 \\
(69.0) \\
\end{array}$ & $\begin{array}{r}179 \\
(20.4) \\
\end{array}$ & $\begin{array}{r}841 \\
(96.0) \\
\end{array}$ & $\begin{array}{r}442 \\
(50.5) \\
\end{array}$ & $\begin{array}{r}138 \\
(15.8) \\
\end{array}$ & $\begin{array}{r}666 \\
(76.0) \\
\end{array}$ & $\begin{array}{r}476 \\
(54.3) \\
\end{array}$ & $\begin{array}{r}614 \\
(70.1) \\
\end{array}$ & $\begin{array}{r}596 \\
(68.0) \\
\end{array}$ & $\begin{array}{r}267 \\
(30.5) \\
\end{array}$ & $\begin{array}{r}65 \\
(7.4) \\
\end{array}$ \\
\hline $\begin{array}{l}\text { New } \\
\text { England }\end{array}$ & 99 & $\begin{array}{r}29 \\
(29.3) \\
\end{array}$ & $\begin{array}{r}52 \\
(52.6) \\
\end{array}$ & $\begin{array}{r}98 \\
(99.0) \\
\end{array}$ & $\begin{array}{r}69 \\
(69.7) \\
\end{array}$ & $\begin{array}{r}70 \\
(70.7) \\
\end{array}$ & $\begin{array}{r}86 \\
(86.9) \\
\end{array}$ & $\begin{array}{r}92 \\
(92.9) \\
\end{array}$ & $\begin{array}{r}78 \\
(78.8) \\
\end{array}$ & $\begin{array}{r}81 \\
(81.8) \\
\end{array}$ & $\begin{array}{r}70 \\
(70.7) \\
\end{array}$ & $\begin{array}{r}37 \\
(37.4) \\
\end{array}$ & $\begin{array}{r}59 \\
(59.6) \\
\end{array}$ & $\begin{array}{r}19 \\
(19.2) \\
\end{array}$ \\
\hline Pacific & 507 & $\begin{array}{r}118 \\
(23.3) \\
\end{array}$ & $\begin{array}{r}159 \\
(31.4) \\
\end{array}$ & $\begin{array}{r}52 \\
(10.3) \\
\end{array}$ & $\begin{array}{r}7 \\
(1.4) \\
\end{array}$ & $\begin{array}{r}478 \\
(94.3) \\
\end{array}$ & $\begin{array}{r}248 \\
(48.9) \\
\end{array}$ & $\begin{array}{r}226 \\
(44.6) \\
\end{array}$ & $\begin{array}{r}425 \\
(83.8) \\
\end{array}$ & $\begin{array}{r}201 \\
(39.6) \\
\end{array}$ & $\begin{array}{r}396 \\
(78.1) \\
\end{array}$ & $\begin{array}{r}351 \\
(69.2) \\
\end{array}$ & $\begin{array}{r}156 \\
(30.8) \\
\end{array}$ & $\begin{array}{r}73 \\
(14.4) \\
\end{array}$ \\
\hline $\begin{array}{l}\text { South } \\
\text { Atlantic }\end{array}$ & 5,930 & $\begin{array}{l}3,195 \\
(53.9)\end{array}$ & $\begin{array}{l}1,757 \\
(29.6)\end{array}$ & $\begin{array}{r}2423 \\
(40.9)\end{array}$ & $\begin{array}{l}3,750 \\
(63.2)\end{array}$ & $\begin{array}{l}3,362 \\
(56.7)\end{array}$ & $\begin{array}{l}3,066 \\
(51.7)\end{array}$ & $\begin{array}{l}2,255 \\
(38.0)\end{array}$ & $\begin{array}{l}2,496 \\
(42.1)\end{array}$ & $\begin{array}{l}3,303 \\
(55.7)\end{array}$ & $\begin{array}{l}3,123 \\
(52.7)\end{array}$ & $\begin{array}{r}993 \\
(16.8)\end{array}$ & $\begin{array}{l}4,109 \\
(69.3)\end{array}$ & $\begin{array}{l}1,227 \\
(20.7)\end{array}$ \\
\hline $\begin{array}{l}\text { West North } \\
\text { Central }\end{array}$ & 1,316 & $\begin{array}{r}724 \\
(55.0) \\
\end{array}$ & $\begin{array}{r}846 \\
(64.3) \\
\end{array}$ & $\begin{array}{r}1084 \\
(82.4) \\
\end{array}$ & $\begin{array}{r}275 \\
(20.9) \\
\end{array}$ & $\begin{array}{r}461 \\
(35.0) \\
\end{array}$ & $\begin{array}{r}704 \\
(53.5) \\
\end{array}$ & $\begin{array}{l}1,030 \\
(78.3) \\
\end{array}$ & $\begin{array}{r}829 \\
(63.0) \\
\end{array}$ & $\begin{array}{r}825 \\
(62.7) \\
\end{array}$ & $\begin{array}{r}597 \\
(45.4) \\
\end{array}$ & $\begin{array}{r}147 \\
(11.2) \\
\end{array}$ & $\begin{array}{l}1,048 \\
(79.6) \\
\end{array}$ & $\begin{array}{r}332 \\
(25.2) \\
\end{array}$ \\
\hline $\begin{array}{l}\text { West South } \\
\text { Central }\end{array}$ & 2,540 & $\begin{array}{l}1,284 \\
(50.6) \\
\end{array}$ & $\begin{array}{l}1,376 \\
(54.2)\end{array}$ & $\begin{array}{r}868 \\
(34.2) \\
\end{array}$ & $\begin{array}{l}1,480 \\
(58.3) \\
\end{array}$ & $\begin{array}{l}1,889 \\
(74.4)\end{array}$ & $\begin{array}{l}1,100 \\
(43.3)\end{array}$ & $\begin{array}{r}477 \\
(18.8) \\
\end{array}$ & $\begin{array}{l}1,406 \\
(55.4)\end{array}$ & $\begin{array}{l}1,025 \\
(40.4)\end{array}$ & $\begin{array}{r}1,341 \\
(52.8) \\
\end{array}$ & $\begin{array}{r}1,419 \\
(55.9) \\
\end{array}$ & $\begin{array}{r}886 \\
(34.9) \\
\end{array}$ & $\begin{array}{r}572 \\
(22.5) \\
\end{array}$ \\
\hline
\end{tabular}


APPENDIX D Store-Level and County-Level Characteristics by Region for PDC RASA, PDC Statins, and HRM Use in Elderly (continued)

\begin{tabular}{|c|c|c|c|c|c|c|c|c|c|c|c|c|c|c|}
\hline $\begin{array}{l}\tilde{\sigma} \\
\stackrel{0}{0} \\
\widetilde{u}\end{array}$ & 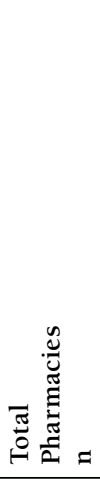 & 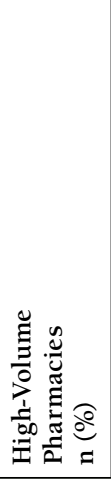 & 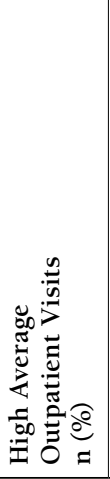 & 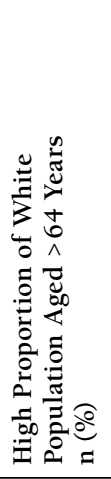 & 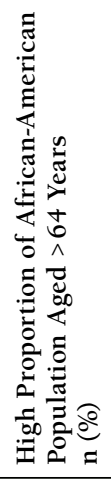 & 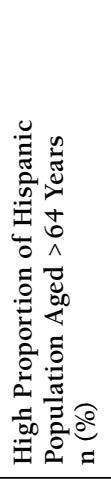 & 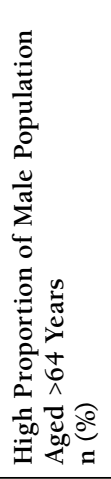 & 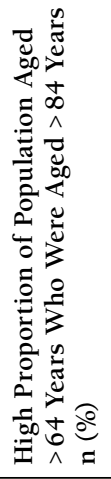 & 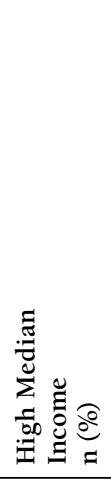 & 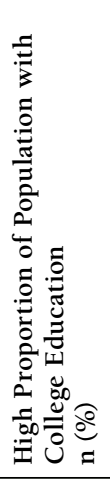 & 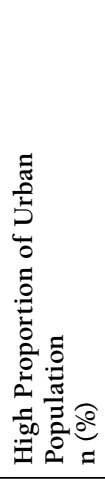 & 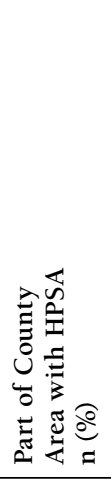 & 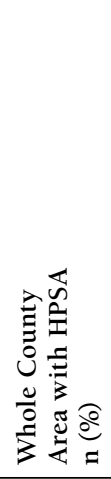 & 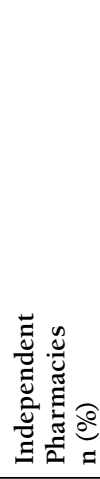 \\
\hline \multicolumn{15}{|c|}{ HRM Use in Elderly } \\
\hline $\begin{array}{l}\text { East North } \\
\text { Central }\end{array}$ & 4,326 & $\begin{array}{l}1,375 \\
(31.8)\end{array}$ & $\begin{array}{l}3,097 \\
(71.6)\end{array}$ & $\begin{array}{l}2,710 \\
(62.6)\end{array}$ & $\begin{array}{l}1,754 \\
(40.6)\end{array}$ & $\begin{array}{r}1,479 \\
(34.2)\end{array}$ & $\begin{array}{l}2,361 \\
(54.6)\end{array}$ & $\begin{array}{l}3,353 \\
(77.5)\end{array}$ & $\begin{array}{l}2,367 \\
(54.7)\end{array}$ & $\begin{array}{l}2,095 \\
(48.4)\end{array}$ & $\begin{array}{r}2,016 \\
(46.6)\end{array}$ & $\begin{array}{l}1,937 \\
(44.8)\end{array}$ & $\begin{array}{l}1,851 \\
(42.8)\end{array}$ & $\begin{array}{r}629 \\
(14.5)\end{array}$ \\
\hline $\begin{array}{l}\text { East South } \\
\text { Central }\end{array}$ & 3,454 & $\begin{array}{l}2,100 \\
(60.8) \\
\end{array}$ & $\begin{array}{l}1,546 \\
(44.8) \\
\end{array}$ & $\begin{array}{r}1,717 \\
(49.7) \\
\end{array}$ & $\begin{array}{l}1,788 \\
(51.8) \\
\end{array}$ & $\begin{array}{r}29 \\
(0.8) \\
\end{array}$ & $\begin{array}{l}1,653 \\
(47.9)\end{array}$ & $\begin{array}{r}893 \\
(25.9) \\
\end{array}$ & $\begin{array}{r}669 \\
(19.4) \\
\end{array}$ & $\begin{array}{l}1,088 \\
(31.5) \\
\end{array}$ & $\begin{array}{r}730 \\
(21.1) \\
\end{array}$ & $\begin{array}{r}783 \\
(22.7) \\
\end{array}$ & $\begin{array}{l}1,880 \\
(54.4) \\
\end{array}$ & $\begin{array}{l}1,287 \\
(37.3) \\
\end{array}$ \\
\hline $\begin{array}{l}\text { Mid- } \\
\text { Atlantic }\end{array}$ & 3,703 & $\begin{array}{l}2,215 \\
(59.8)\end{array}$ & $\begin{array}{l}2,836 \\
(76.6)\end{array}$ & $\begin{array}{l}2,151 \\
(58.1)\end{array}$ & $\begin{array}{l}1,989 \\
(53.7)\end{array}$ & $\begin{array}{l}1,993 \\
(53.8)\end{array}$ & $\begin{array}{l}1,911 \\
(51.6)\end{array}$ & $\begin{array}{l}3,617 \\
(97.7)\end{array}$ & $\begin{array}{l}2,163 \\
(58.4)\end{array}$ & $\begin{array}{l}2,232 \\
(60.3)\end{array}$ & $\begin{array}{l}2,244 \\
(60.6)\end{array}$ & $\begin{array}{l}1,573 \\
(42.5)\end{array}$ & $\begin{array}{l}1,890 \\
(51.0)\end{array}$ & $\begin{array}{l}1,485 \\
(40.1)\end{array}$ \\
\hline Mountain & 1,866 & $\begin{array}{r}714 \\
(38.3) \\
\end{array}$ & $\begin{array}{r}649 \\
(34.8) \\
\end{array}$ & $\begin{array}{l}1,304 \\
(69.9) \\
\end{array}$ & $\begin{array}{r}242 \\
(13.0) \\
\end{array}$ & $\begin{array}{l}1,785 \\
(95.7) \\
\end{array}$ & $\begin{array}{r}936 \\
(50.2) \\
\end{array}$ & $\begin{array}{r}409 \\
(21.9) \\
\end{array}$ & $\begin{array}{l}1,384 \\
(74.2)\end{array}$ & $\begin{array}{l}1,198 \\
(64.2) \\
\end{array}$ & $\begin{array}{l}1,390 \\
(74.5) \\
\end{array}$ & $\begin{array}{l}1,197 \\
(64.2) \\
\end{array}$ & $\begin{array}{r}633 \\
(33.9) \\
\end{array}$ & $\begin{array}{r}197 \\
(10.6) \\
\end{array}$ \\
\hline $\begin{array}{l}\text { New } \\
\text { England }\end{array}$ & 227 & $\begin{array}{r}43 \\
(18.9) \\
\end{array}$ & $\begin{array}{r}132 \\
(58.2) \\
\end{array}$ & $\begin{array}{r}220 \\
(96.9) \\
\end{array}$ & $\begin{array}{r}129 \\
(56.8) \\
\end{array}$ & $\begin{array}{r}129 \\
(56.8) \\
\end{array}$ & $\begin{array}{r}171 \\
(75.3) \\
\end{array}$ & $\begin{array}{r}200 \\
(88.1) \\
\end{array}$ & $\begin{array}{r}180 \\
(79.3) \\
\end{array}$ & $\begin{array}{r}189 \\
(83.3) \\
\end{array}$ & $\begin{array}{r}129 \\
(56.8) \\
\end{array}$ & $\begin{array}{r}96 \\
(42.3) \\
\end{array}$ & $\begin{array}{r}127 \\
(56.0) \\
\end{array}$ & $\begin{array}{r}27 \\
(11.9) \\
\end{array}$ \\
\hline Pacific & 1,250 & $\begin{array}{r}235 \\
(18.8) \\
\end{array}$ & $\begin{array}{r}430 \\
(34.4) \\
\end{array}$ & $\begin{array}{r}150 \\
(12.0) \\
\end{array}$ & $\begin{array}{r}276 \\
(22.1) \\
\end{array}$ & $\begin{array}{r}1,131 \\
(90.5) \\
\end{array}$ & $\begin{array}{r}481 \\
(38.5) \\
\end{array}$ & $\begin{array}{r}705 \\
(56.4) \\
\end{array}$ & $\begin{array}{l}1,068 \\
(85.4) \\
\end{array}$ & $\begin{array}{r}601 \\
(48.1) \\
\end{array}$ & $\begin{array}{r}994 \\
(79.5) \\
\end{array}$ & $\begin{array}{r}838 \\
(67.0) \\
\end{array}$ & $\begin{array}{r}412 \\
(33.0) \\
\end{array}$ & $\begin{array}{r}155 \\
(12.4) \\
\end{array}$ \\
\hline $\begin{array}{l}\text { South } \\
\text { Atlantic }\end{array}$ & 8,016 & $\begin{array}{l}4,619 \\
(57.6) \\
\end{array}$ & $\begin{array}{l}2,434 \\
(30.4) \\
\end{array}$ & $\begin{array}{l}3,048 \\
(38.0) \\
\end{array}$ & $\begin{array}{l}5,580 \\
(69.6) \\
\end{array}$ & $\begin{array}{l}4,377 \\
(54.6) \\
\end{array}$ & $\begin{array}{l}3,929 \\
(49.0) \\
\end{array}$ & $\begin{array}{l}2,830 \\
(35.3) \\
\end{array}$ & $\begin{array}{l}3,096 \\
(38.6) \\
\end{array}$ & $\begin{array}{l}4,358 \\
(54.4) \\
\end{array}$ & $\begin{array}{l}4,101 \\
(51.2) \\
\end{array}$ & $\begin{array}{l}1,442 \\
(18.0) \\
\end{array}$ & $\begin{array}{l}5,389 \\
(67.2) \\
\end{array}$ & $\begin{array}{l}1,897 \\
(23.7) \\
\end{array}$ \\
\hline $\begin{array}{l}\text { West North } \\
\text { Central }\end{array}$ & 2,065 & $\begin{array}{l}1,075 \\
(52.1) \\
\end{array}$ & $\begin{array}{l}1,331 \\
(64.5) \\
\end{array}$ & $\begin{array}{l}1,796 \\
(87.0) \\
\end{array}$ & $\begin{array}{r}333 \\
(16.1) \\
\end{array}$ & $\begin{array}{r}607 \\
(29.4) \\
\end{array}$ & $\begin{array}{l}1,258 \\
(60.9) \\
\end{array}$ & $\begin{array}{l}1,631 \\
(79.0) \\
\end{array}$ & $\begin{array}{l}1,303 \\
(63.1) \\
\end{array}$ & $\begin{array}{l}1,188 \\
(57.5)\end{array}$ & $\begin{array}{r}817 \\
(39.6) \\
\end{array}$ & $\begin{array}{r}255 \\
(12.4) \\
\end{array}$ & $\begin{array}{l}1,553 \\
(75.2) \\
\end{array}$ & $\begin{array}{r}643 \\
(31.1) \\
\end{array}$ \\
\hline $\begin{array}{l}\text { West South } \\
\text { Central }\end{array}$ & 3,962 & $\begin{array}{l}1,931 \\
(48.7)\end{array}$ & $\begin{array}{l}2,012 \\
(50.8)\end{array}$ & $\begin{array}{l}1,337 \\
(33.8)\end{array}$ & $\begin{array}{l}2,349 \\
(59.3)\end{array}$ & $\begin{array}{l}2,912 \\
(73.5)\end{array}$ & $\begin{array}{l}1,727 \\
(43.6)\end{array}$ & $\begin{array}{r}790 \\
(19.9)\end{array}$ & $\begin{array}{l}2,205 \\
(55.7)\end{array}$ & $\begin{array}{l}1,278 \\
(32.3)\end{array}$ & $\begin{array}{l}2,029 \\
(51.2)\end{array}$ & $\begin{array}{l}2,120 \\
(53.5)\end{array}$ & $\begin{array}{l}1,364 \\
(34.4)\end{array}$ & $\begin{array}{l}1,070 \\
(27.0)\end{array}$ \\
\hline
\end{tabular}

